\title{
Magma Geopark-projektet - IGC 33-ekskursion til Norge
}

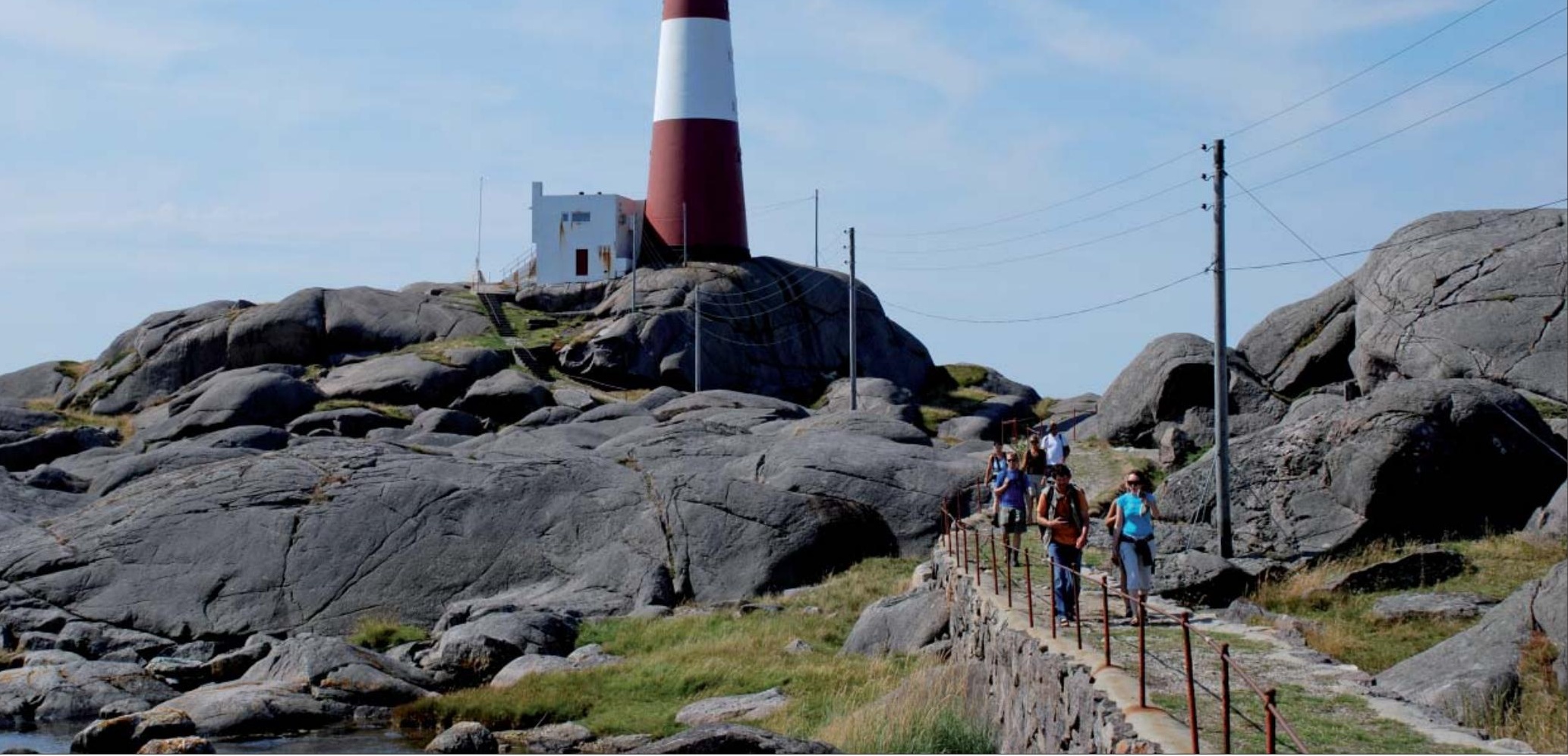

Eigerøy-fyrtårnet er bygget på anorthosit. (Foto: Pål Thjømøe)

Af J. Richard Wilson, Geologisk Institut, Aarhus Universitet

\section{I forbindelse med " $33^{\text {rd }}$ Interna-} tional Geological Congress", der blev afholdt i Oslo i perioden 6. - 14. august $i$ år, var der en række ekskursioner. Disse fandt sted både før, under og efter selve kongressen. Ekskursionerne gik blandt andet til Svalbard, Island, Færøerne, Kolahalvøen - og mange andre steder i Skandinavien. En af ekskursionerne fandt sted i Magma Geopark-området i Sydvestnorge. Den skal vi høre lidt nærmere om her.

En geopark er et område med en speciel geologisk arv, tilrettelagt for lokalbefolkning og turister. Der er p.t. 33 geoparker $i$ Europa. UNESCO har for nylig modtaget en ansøgning om at optage "Magma Geopark" i det Europæiske Geopark Netværk. MGP dækker et område på $2.329 \mathrm{~km}^{2}$ i Sydnorge mellem Stavanger og Kristiansand.

Der var 12 deltagere på ekskursionen: 3 fra Californien, 1 fra Australien, 2 fra Finland, 1 fra Grækenland, 1 fra Sverige og 4 fra Norge, samt tre ledere: Brian Robins fra Bergen, undertegnede, samt Pål Thjømøe fra MGP. Pål er cand. scient. fra Geologisk Institut ved Aarhus Universitet (1995) med speciale i endogen geologi. Han har siden arbejdet i naturstensindustrien i Norge og er nu projektleder for MGP. Brian og undertegnede har haft forskningsprojekter i Rogaland siden 1985 .

\section{Rogaland Anorthosit-provinsen}

Rogaland Anorthosit-provinsen og dennes kontaktbjergarter danner kernen af MGP. Der er flere store anorthositlegemer, der intruderede i et gnejskompleks for 930 millioner år siden - samt Europas største lagdelte intrusion. Området indeholder en af de største ilmenitminer i verden. De yngste bjergarter i området er basaltiske gange med en alder på 620 millioner år. Området, som har hævet sig ca. $20 \mathrm{~km}$, siden anorthositerne blev dannet, har været dækket af is flere gange under istiden. Langt de fleste bjergarter i området stammer fra magma; derfor navnet - Magma Geopark.

Bjergartstypen anorthosit er relativt sjælden på verdensplan, men ret almindelig $\mathrm{i}$ Rogaland. Den består af $>90 \%$ af mineralet plagioklas-feldspat. Forvitringsprodukterne af anorthosit er meget fattige på næringsstoffer. Dette resulterer i et karakteristisk nøgent, afrundet klippelandskab uden træer og anden vegetation (fotoet ovenfor). Blotningerne af anorthosit blev studeret på nært hold af ekskursionsdeltagerne (figurerne øverst på næste side). Mineralet plagioklas kan vise et karakteristisk farvespil, som kaldes for labradorescens. Dette fænomen er veludviklet nogle steder i Rogaland. Der 

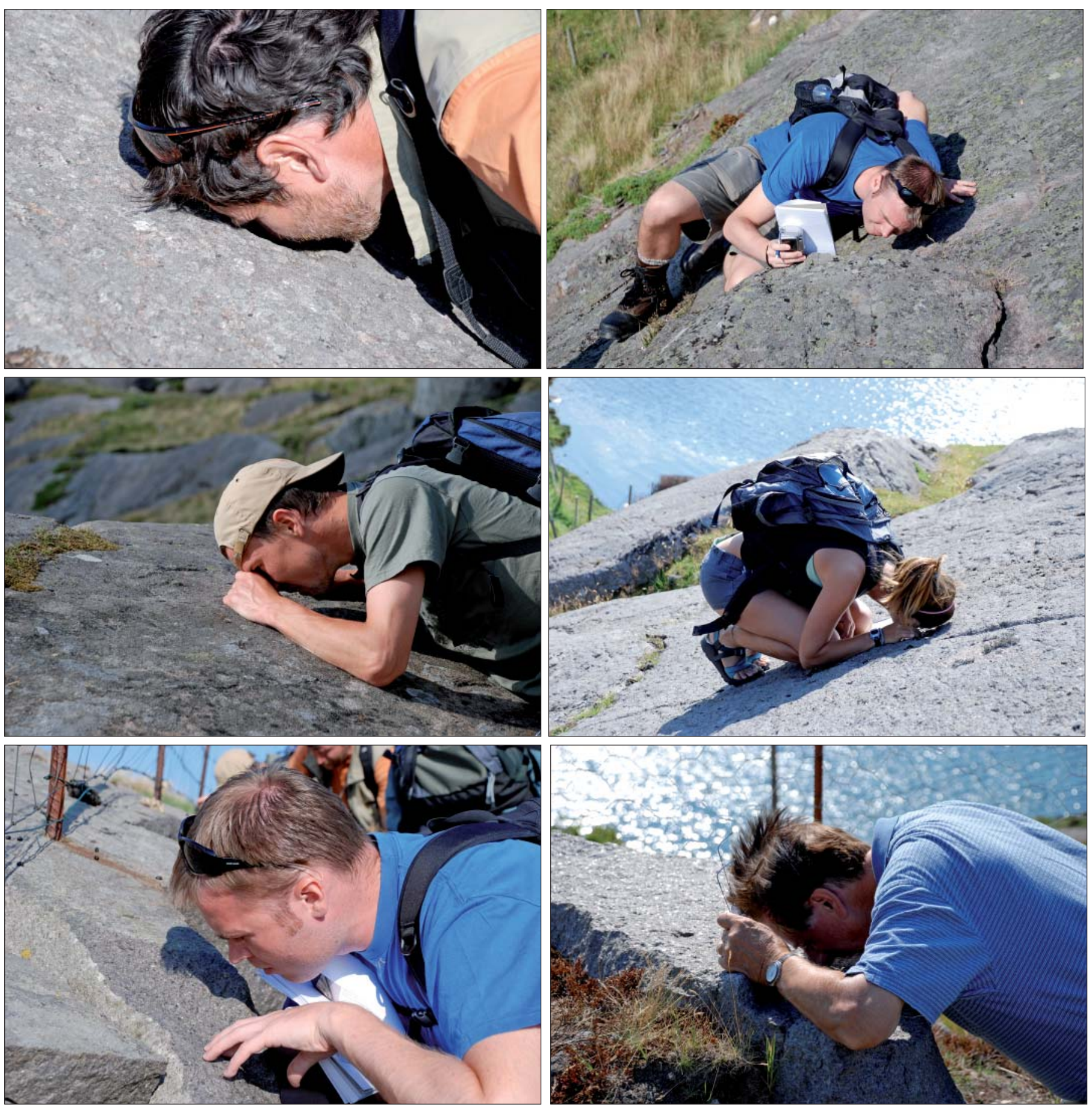

Anorthosit studeres intensivt under ekskursionen. (Fotos: Pål Thjømøe)

er to store stenbrud vest for Egersund, hvor bjergarten er udvundet netop på grund af farvespillet. Blokke af massiv anorthosit, der måler ca. 3 × 2 x $1 \mathrm{~m}$, bliver skåret ud med en roterende kabelsav - hvor "wiren" er imprægneret med diamanter (fotoet til højre). Blokkene sendes til Larvik til videre forarbejdning på samme måde som den lokale bjergartstype larvikit (som blev kåret som Norges "Nationale Bjergart" i 2008). Anorthosit fra Rogaland med farvespil sælges under navnene "Labrador Antique" (www.granit.no) og "Blue Antique" (www. larvik-granite.no).

Bjerkreim-Sokndal-intrusionen

Den største lagdelte intrusion i Europa hed-
Den massive anorthosit med plagioklas, der viser farvespil, skcres ud $i$ store blokke. (Foto: Forfatteren)

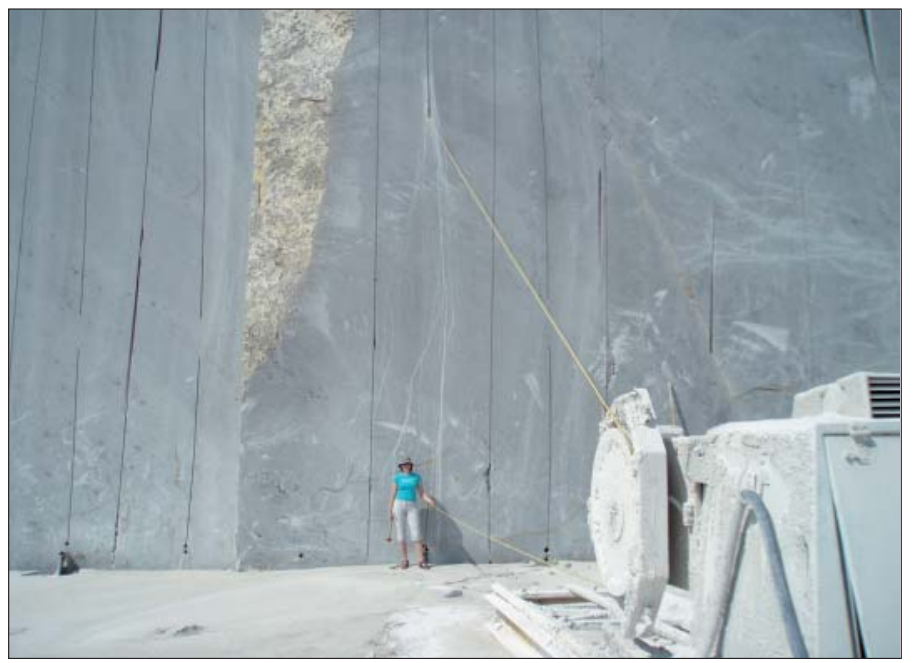




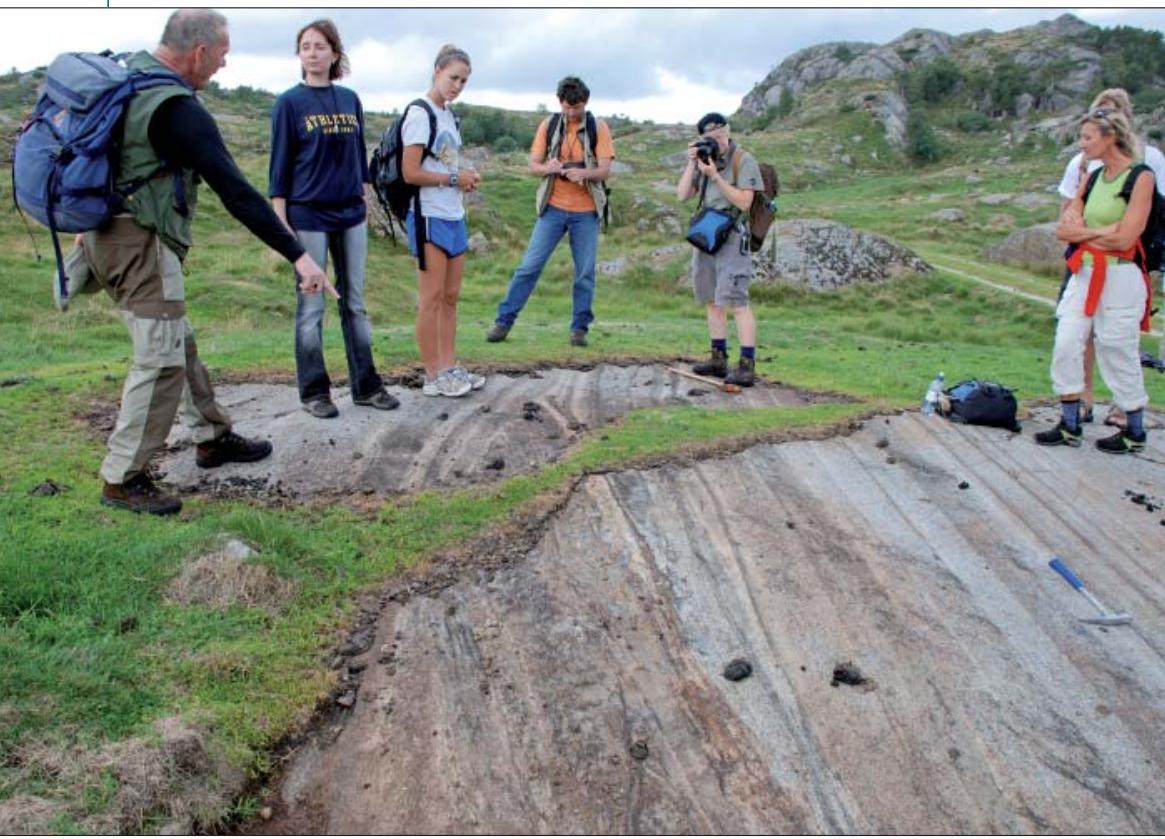

Lagdelt gabbronorit fra Bjerkreim-Sokndal-intrusionen. Stratigrafisk op er til højre. Brian Robins peger på en indeslutning af gnejs i midten af billedet. (Foto: Pål Thjømøe)

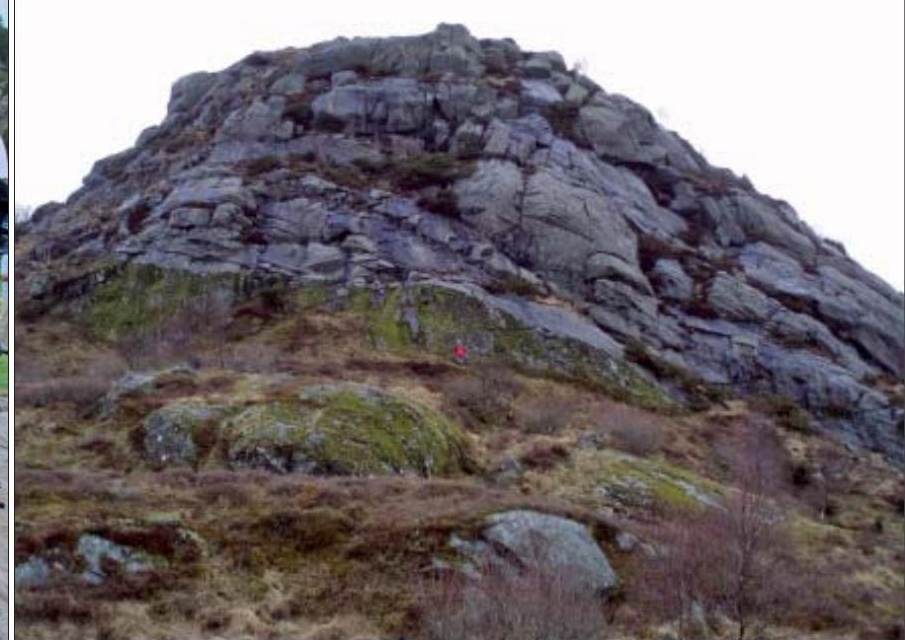

Den nedre grcense af bjergarterne dannet efter det sidste magmainfluks i den lagdelte Bjerkreim-Soknda-intrusion er blottet på Storeknuten. Gabbronoritiske bjergarter i toppen af MCU 5 (som er rig på mørke mineraler samt apatit) forvitrer til mosdcekkede overflader. Anorthosit i bunden af MCU 6 er meget fattig på mørke mineraler og har ingen apatit; den forvitrer til vegetationsfrie overflader. Den skarpe grcense mellem MCU 5 og MCU 6 er synlig ca. 2 m over personen midt på billedet. (Foto: Forfatteren) der Bjerkreim-Sokndal-intrusionen. Den dækker et område på $230 \mathrm{~km}^{2}$ i MGP og har en længde på $40 \mathrm{~km}$ og en maksimal bredde på $15 \mathrm{~km}$. Magmakammeret udviklede sig i 6 trin, hvor nyt magma blev intruderet $i$ kammeret. Bjergartstyperne i den lagdelte intrusion dækker et meget stort spektrum fra anorthosit gennem troktolit (der består af mineralerne olivin + plagioklas), norit (orthopyroksen + plagioklas), gabbronorit (orthopyroksen + klinopyroksen + plagioklas \pm apatit), jotunit (olivin + orthopyroksen + klinopyroksen + plagioklas + alkali feldspat + apatit), mangerit ( $>$ alkali feldspat end $i$ jotunit) til charnockit (en granit med orthopyroksen). Bjergarterne er ofte lagdelt på centimeterskala (foto øverst til venstre). Intrusionens lagdelte struktur betyder, at vi kan estimere tykkelser. Den totale tykkelse af intrusionen er $>7.000 \mathrm{~m}$. Taget til magmakammeret er blevet eroderet bort. Xenolitter (fragmenter af "fremmede" bjergarter) er almindelige i de lagdelte bjergarter. Disse repræsenterer fragmenter af taget til magmakammeret, der blev revet løs og sank ned gennem magmaet, til de nåede bunden - krystallisationsfronten. De fleste xenolitter er af gnejs. Det viser, at magamakammerets tag (som mangler nu) engang bestod af gnejsiske bjergarter.

Intrusionen deles op i 6 "Megacykliske Enheder" (MCU), som størknede fra successive influkser af magma. Grænserne mellem MCUerne karakteriseres som en "tilbagegang" til mere "primitive" bjergarter med færre mineraler. Ved grænsen mellem MCU 5 og MCU 6 bliver gabbronorit (med 6 mineraler: plagioklas + to pyroksener + ilmenit + magnetit + apatit) overlejret af anorthosit (med kun plagioklas) (foto øverst til højre). Tilstedeværelsen af mørke mineraler betyder, at gabbronorit forvitrer relativt let. Mineralet apatit indeholder fosfor, som er en vigtig komponent i gødning. Kombinationen af de mørke mineraler og apatit betyder, at forvitringsprodukterne fra gabbronorit er meget næringsrige. Alle de produktive landbrug ligger i områder underlejret af gabbronorit eller jotunit.

\section{Parken med de mange miner}

Der er over 100 miner i Magma Geoparkområdet. Den største del af aktiviteten har været rettet mod jern-titan-malme, men nikkel, kobber, molybdæn og wolfram har alle været vigtige igennem årene. $\mathrm{Nu}$ er der kun én aktiv mine i området (Tellnes) - men det er til gengæld den største titanmine i Europa (foto nedenfor). Udvinding af jern-titanmalm begyndte ca. $6 \mathrm{~km}$ øst for Egersund i 1785 fra nogle relativt små, men rige forekomster af mineralet ilmenit $\left(\mathrm{FeTiO}_{3}\right)$. Det var jern, der var af interesse til at begynde med - men det store indhold af titan gjorde, at det var svært at smelte. Senere var indholdet af titan det vigtigste. Tellnes er en "open pit-mine", hvor hele bjergarten knuses, før

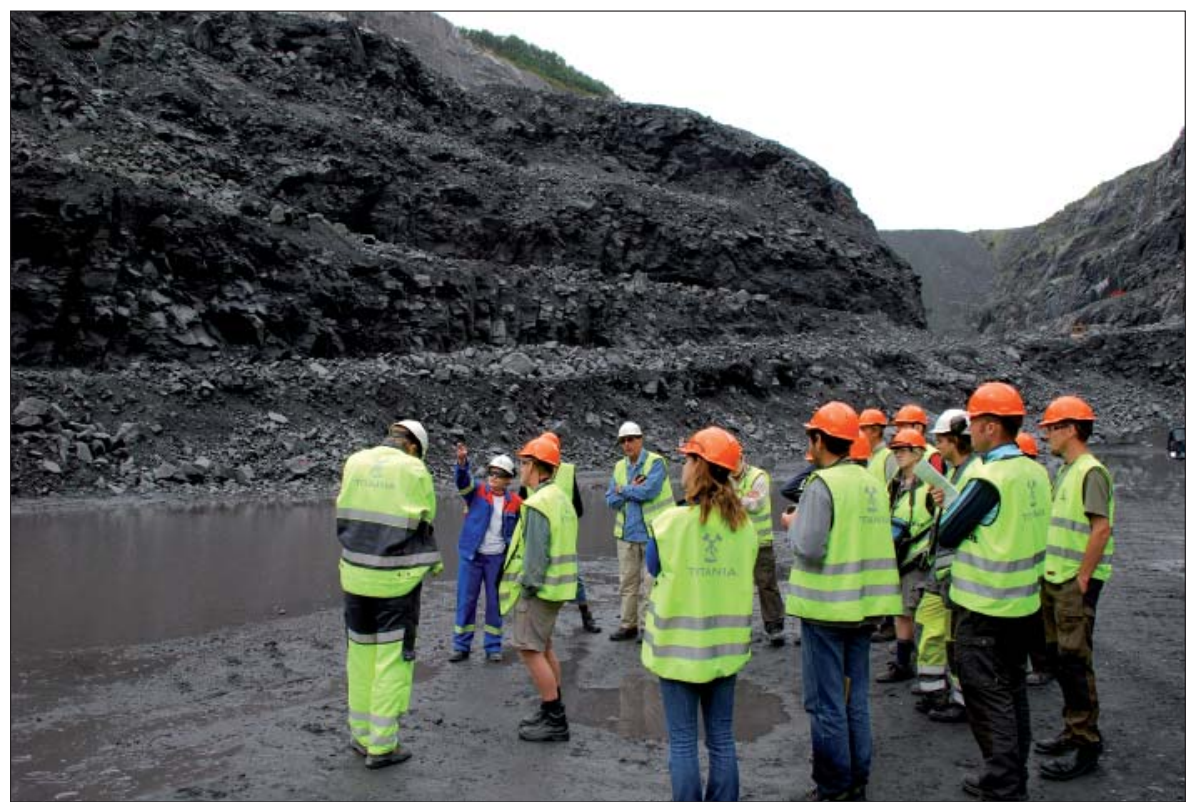

Ekskursionsdeltagerne i beskyttelsestøj kigger på den sorte ilmenitnorit, der giver det hvide produkt $\mathrm{TiO}_{2}$-pigment. (Foto: Pål Thjømøe) 


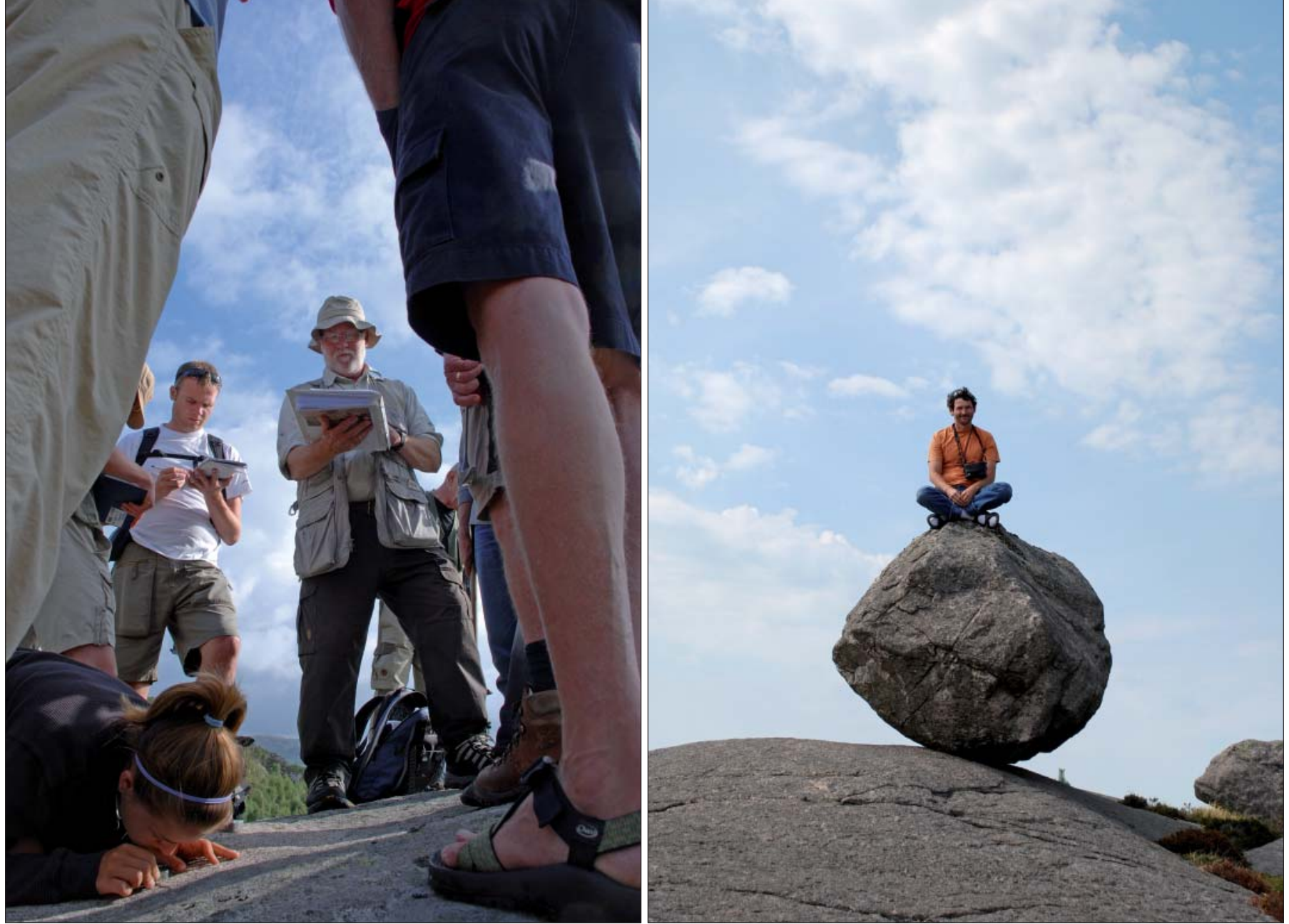

Venstre: Der blev forklaret og noteret flittigt samtidigt med, at bjergarterne blev undersøgt på tcet hold under ekskursionen. Højre: En russer bosat i Finland fungerer som skala på en vandreblokke i Sydnorge. (Fotos: Pål Thjømøe)

ilmenitmalmen separeres. Bjergarten er en ilmenitnorit med $\sim 30 \%$ ilmenit. Ilmenit er et sort mineral, mens det vigtigste produkt, titanoxid-pigment er hvidt. $\mathrm{TiO}_{2}$-pigment bruges hovedsageligt i maling, plastik og papir, men også i solcreme, make-up og i

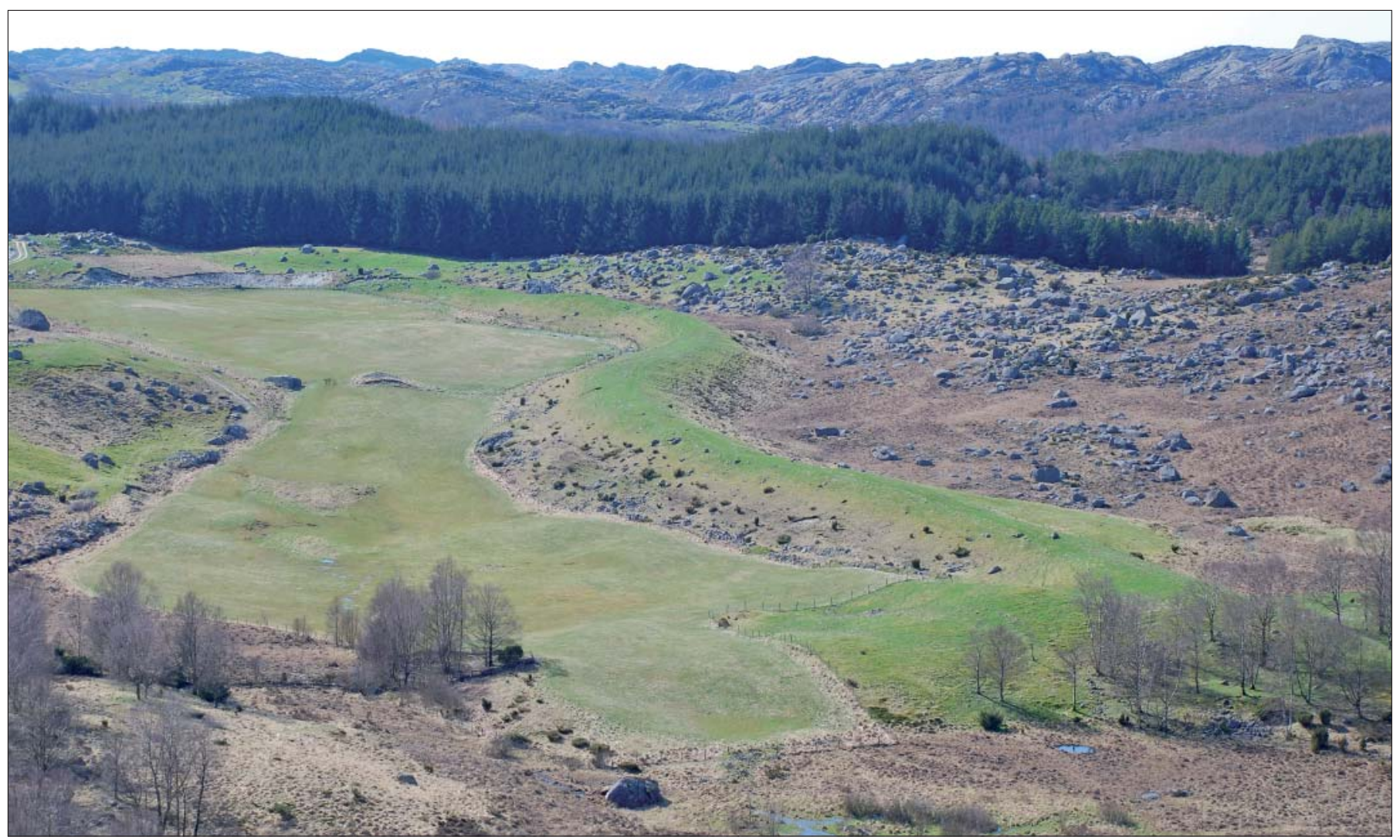

Den velbevarede esker "St. Olav's Orm” danner en markant ryg, der snor sig gennem landskabet. Til højre for "ormen” er overfladen dcekket af mange vandreblokke; til venstre er blokkene blevet fjernet for at dyrke jorden. (Foto: Pål Thjømøe) 


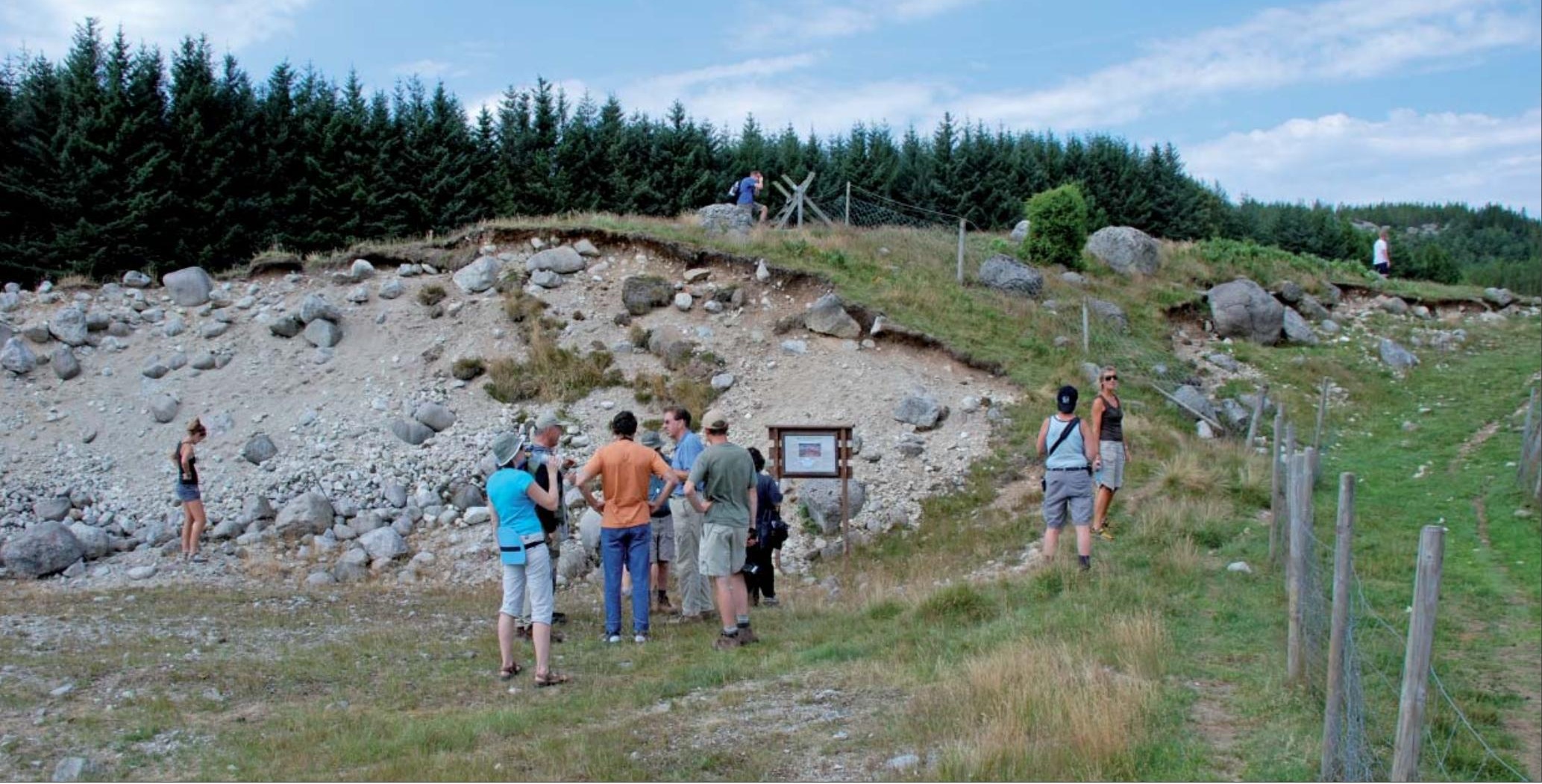

En grusgrav blotter et snit gennem St. Olav's Orm. Her kan man se, at ormen består af materiale med stor variation i kornstørrelse, fra blokke i meter-størrelse gennem grus og sand til silt. Udgravningen kan ses til venstre i billedet nederst på foregående side. (Foto: Pål Thjømøe)

mange piller. Det indgår også i nogle madprodukter, hvor det er kendt som "E171".

Området har været dækket af gletschere flere gange under istiderne. Den sidste istid har efterladt mange spor. Vandreblokke forekommer stort set alle steder (fotos øverst på foregående side). Der er mange aflejringer fra moræner i området. En af de meste instruktive er en meget velbevaret esker (lang, bugtet ryg dannet af postglacial grus og andre sedimenter), kendt som "St. Olav's Orm" (foto nederst på foregående side). Ormen består af en op til $10 \mathrm{~m}$ tyk ryg, der snor sig gennem landskabet $\mathrm{i} \sim 2$ $\mathrm{km}$. For nogle år siden begyndte den lokale gårdejer at grave ryggen væk for at udnytte gruset. Han blev standset og fik i stedet en kompensation. Heldigvis er langt det meste af "ormen" bevaret, og der, hvor der blev gravet ud, kan man se, hvad den består af (foto ovenfor).

\section{Klatretur på anorthosit}

På den sidste ekskursionsdag fik deltagerne mulighed for at følge en klatrerute (på anorthosit selvfølgelig!) etableret af ViaFjord A/S (www.viafjord.no) i samarbejde med Magma Geopark. Det havde regnet noget $i$ løbet af dagen, hvilket betød, at der var en del vand $\mathrm{i}$ vandfaldene. Et af disse var på klatreruten. Forfatteren meldt sig frivilligt til at tage billeder af vandfaldet på afstand (se foto til højre). De 9, der tog imod udfordringen, vil længe huske den sidste dag af ekskursionen til Magma Geopark (fotos øverst på næste side)!

\section{Yderligere info}

\section{Lces mere om magmageopark på:}

www.magmageopark.com

\section{Link til ekskursionsguiden:}

http://www.33igc.org/fileshare/filArkiv-

Root/coco/FieldGuides/No\%2026\%20 Magma\%20Geopark.pdf

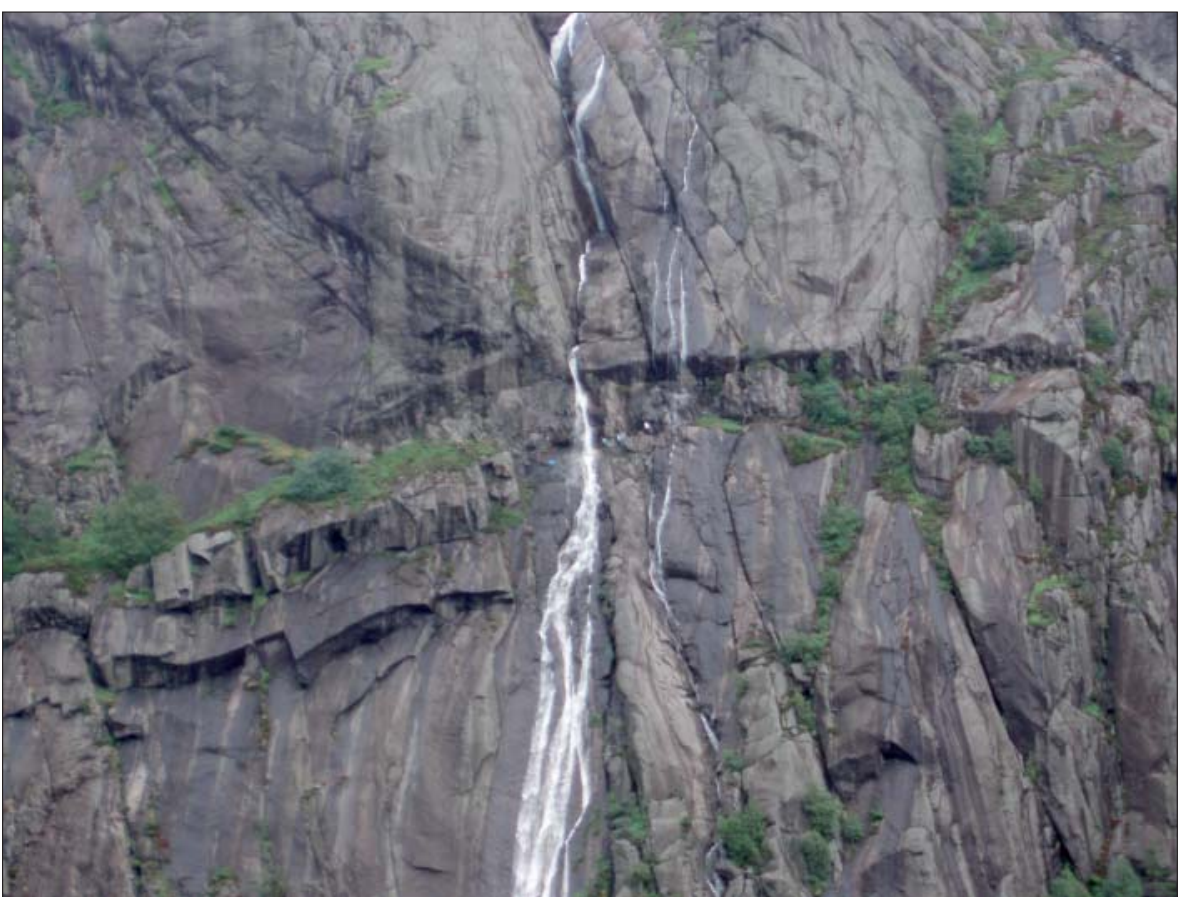

Klatreruten passerer fra venstre mod højre gennem vandfaldet ca. midt i billedet. Nogle af klatrerne kan ses i ncerheden af vandfaldet.(Foto: Forfatteren) 


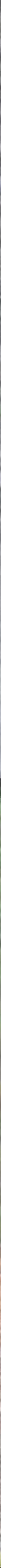

Passagen gennem vandfaldet var en stor udfordring. Klatrerne havde grund til at vœre stolte af deres tapperhed! (Fotos: Pål Thjømøe) 